\title{
A Comparison of Nitrate Distribution in Shallow Groundwater of Two Agricultural Areas in Sri Lanka and in Japan
}

\section{Gunatilake, S.K. ${ }^{1}$ and Iwao, Y. ${ }^{2}$}

${ }^{1}$ Department of Natural Resources, Faculty of Applied Sciences, Sabaragamuwa University of Sri Lanka, Belihuloya, P.O Box 02. sksg@sab.ac.lk

${ }^{2}$ Department of Civil Engineering, Saga University, Saga 840, Japan, iwaoy@cc.saga-u.ac.jp

\begin{abstract}
This paper compares the effects of adding fertilizer in nitrate pollution of groundwater in the Udunuwara area in Sri Lanka and the Shiroishi Plain in Japan. Excessive application of nitrogen fertilizers to soils contributes to contamination of groundwater by nitrates. As nitrate is one of the most identified contaminant in groundwater several environmental protection agencies maximum contamination level for nitrate is $10 \mathrm{mg} / \mathrm{l}$ as $\mathrm{NO}_{3}-\mathrm{N}$. The problem becomes severe in rural areas where people depend entirely on dug wells in the shallow groundwater table for their drinking water supply. Several locations were selected from the Udunuwara area of Sri Lanka for the detailed study. Nineteen shallow dug wells and 4 deep tube wells were selected for water sampling beginning of January to March 1998.
\end{abstract}

Shiroishi Plain in Japan reclaimed from the Ariake Sea has a soil layer consisting of Ariake clay. The total 82 drug wells of average depth $1.5 \mathrm{~m}$ had been drilled around the area. Sample were collected in December 2000 and continued for one year around. Nitrate concentration in groundwater was measured by Cadmium reduction method.

The results showed a varying nitrate distribution pattern compared to that the Udunuwara area. The effect of fertilizer application on groundwater depends on soil type, fertilizer type and amount used, crop type and climatic condition. The highly permeable soil around Udunuwara area showed that shallow groundwater is highly vulnerable for nitrate than the poorly drained soil of the Shiroishi Plain in Japan. As the people living in Shiroishi Plain use deep groundwater for domestic purposes, drinking water is safe (less than Maximum Contaminated Level for nitrate in drinking water for Japan-10 mg/l as $\mathrm{NO}_{3}-\mathrm{N}$ ) as far as the nitrate contamination is concerned. The results of these studies suggest that applying the correct rate of $\mathrm{N}$ fertilizer at the optimum time would have a substantial effect on reducing nitrate- $\mathrm{N}$ losses.

Key Words: Nitate Contamination, Groundwater, Land Reclamation, Fertilizer 


\section{Introduction}

Pollution of groundwater by nitrates is presently receiving increasing attention in the world. All living systems need nitrogen to exist as it is used to build many essential components such as proteins, DNA, RNA, and vitamins as well as hormones and enzymes. However, it becomes potentially hazardous when present in drinking water at significantly high concentrations. Groundwater is one of the most important natural resources and the main source of drinking water in many countries of the world. Studies on the effect of fertilization and groundwater pollution in intensive agricultural areas are of prime importance. The current research study was aimed to investigate how far the problem as of excessive nitrates has affected the quality of regional groundwater under different climatic conditions (wet zone in Sri Lanka and lowland in Japan). The behavior of the geochemistry of nitrate distribution during periodical application of fertilizers in the wet zone on Sri Lanka and the lowlands in Japan was compared.

Nitrate rich drinking water, is potentially harmful to human health, particularly to infants causing the condition known as methemoglobinemia, also called "blue baby syndrome" (Dissanayake et al. 1984) (Figure 1). It is therefore recommended that pregnant women and lactating mothers should limit the nitrate consumption. Possible connections between nitrate and other health problems such as nervous system disorders, cancer, and heart damage, are not well documented.

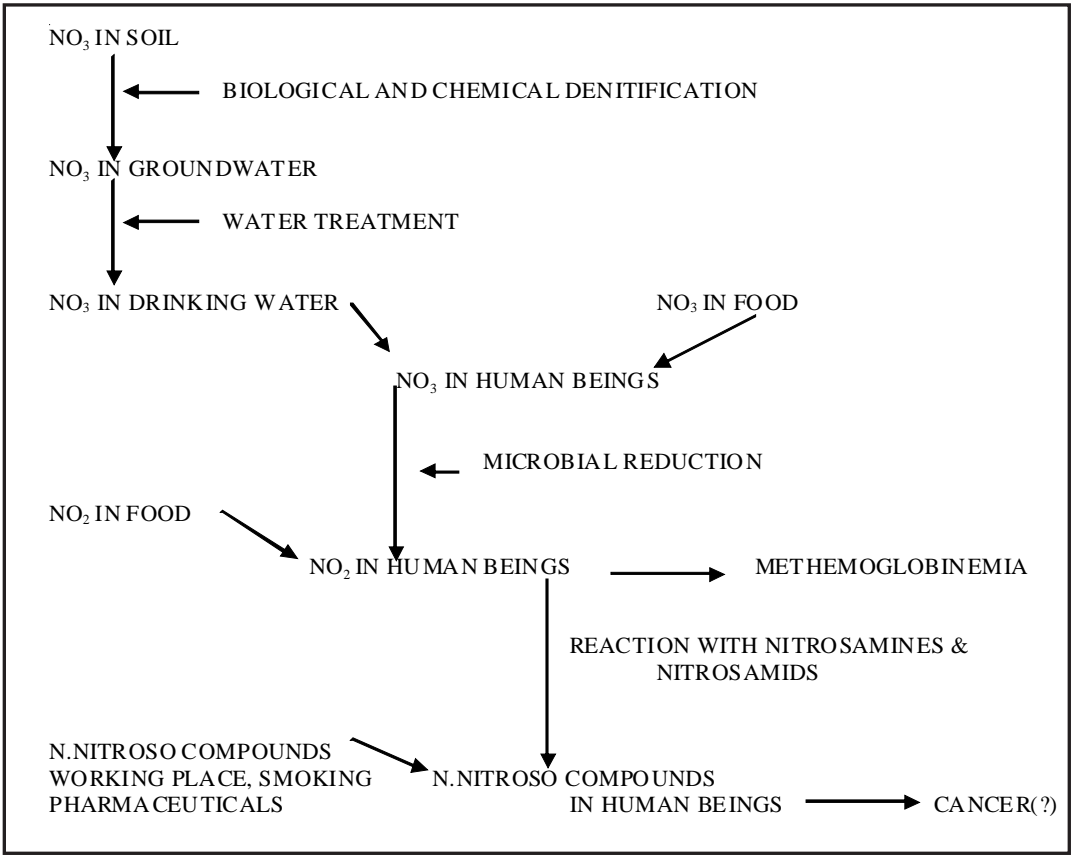

Figure 1: Nitrate pathways and metabolism (Paul and Clark, 1989) 
According to the study on the distribution of nitrates in the groundwater of Sri Lanka, it has been suggested that a direct relationship exists between the nitrate concentrations in groundwater and paddy cultivation, and with the population distribution (Dissanayake and Weerasooriya, 1987). Dense paddy cultivations in the wetlands of Sri Lanka showed the maximum average nitrate levels, polluting drinking water sources. Since a large percentage of the village people entirely depend on the shallow groundwater through shallow dug wells, the problem of nitrate contamination becomes more crucial (Dissanayake et al., 1984). The Udunuwara area south west of Kandy in the central Sri Lanka was selected to study the effect of application of nitrogenous fertilizers on nitrate contamination of groundwater during the Maha (January - April) paddy cultivation season.

The Shiroishi Plain is lowland reclaimed from the Ariake Sea in several stages during the last 200 years (Figure 2). It is the most developed agricultural area in Japan and largest paddy cultivation in the Kyushu Island. As the area consists of poorly drained Ariake clay, there are modified creeks and subsurface drainage systems made to make the area suitable for agriculture. These modified creeks and subsurface drainage systems however base a risk for surface water quality, shallow groundwater and may also affect the deep groundwater table. Investigations therefore focused on the effect of application of fertilizer on shallow and deep groundwater under land modification and intensive agricultural practices.

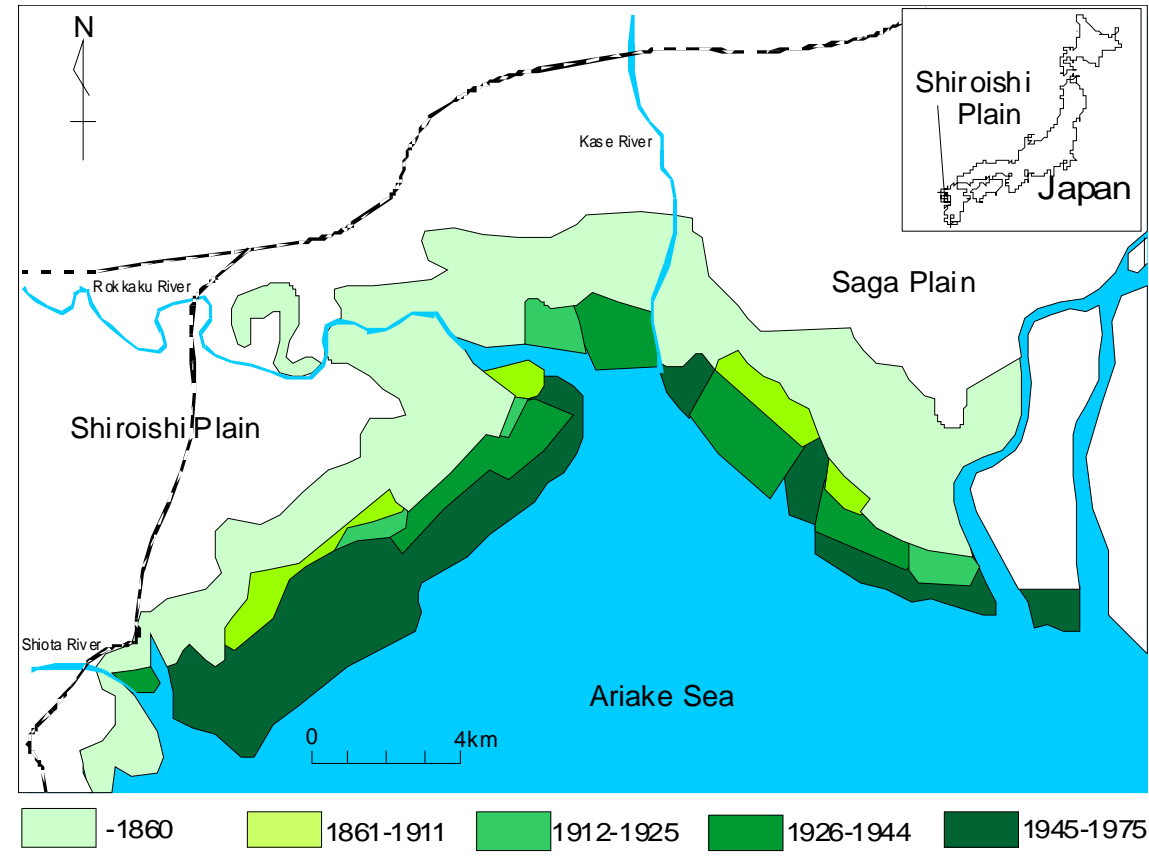

Figure 2: Reclamation Stages of the Shiroishi and Saga Plain 


\section{Methodology}

A total number of 115 groundwater samples were collected from 23 selected dug wells and 4 tube wells of the Udunuwara area in Sri Lanka, at frequent intervals during January to March 1998, which coincides with the Maha season. An attempts was made to select the sampling locations within the paddy fields or adjacent to paddy fields or along the flow of groundwater from paddy cultivated areas. Reference sampling points were also selected at close proximity. The sampling was carried out every 2 weeks in order to observe the variation of the nitrate concentration in groundwater caused by the application of nitrate fertilizers to the adjacent paddy fields. All-important information on location, hydrology, geology, landuse etc. was also recorded.

Water samples collected into pre-cleaned plastic bottles which were quickly transported to the laboratory for immediate analysis and to prevent any influence of microbiological activity. Samples were analysed for nitrate using the cadmium reduction method. DR/2000 HACH programmable spectrophotometer was utilized for the colorimetric determination using $\mathrm{HACH}$ powder pillows.

The field study of the Sriroishi Plain in Japan commenced in December 2000 and a total of 82 numbers of shallow wells were drilled within the uppermost soft Ariake clay (Figure 3). The shallow well were approximately $1.5 \mathrm{~m}$ deep. A base map of the Shiroishi Plain with 1 square kilometer grid reference was used for sampling. Locations were selected within the study area, making sure that the only possible source for nitrate fertilizers. Water from the shallow wells was sampled into pre-cleaned plastic bottles using a submersible type pump. Before each sample is collected, the static well water depth was measured. Several samples of drainage water at the outlets of the creeks passing into the interceptor drains, deep groundwater (around $80 \mathrm{~m}$ deep) and interceptor drain water samples were measured at monthly intervals. The portable HACH DR/2010 spectrophotometer was used for in-situ analysis. As the farmers use nitrogen fertilizers and phosphorus fertilizers together in their land nitrate, ammonia and phosphate concentrations of the water samples were measured. The nitrate concentrations in the samples were measured by the cadmium reduction method using the Nitraver 5 powder pillows. The $\mathrm{pH}$ of the water sample was obtained using $\mathrm{pH}$ indicator papers. 


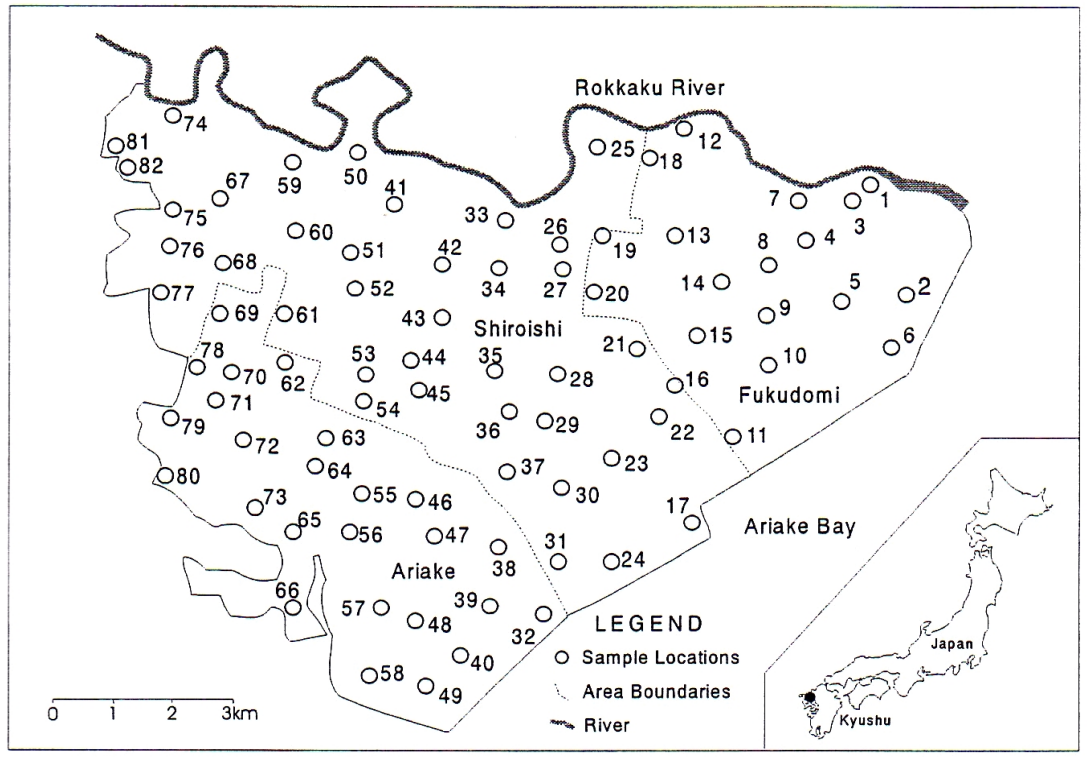

Figure 3: Location Map of the Study Area

\section{Results and Discussion}

(a) Case study : Udunuwara Area in Kandy District in Sri Lanka

Results of the chemical analysis indicate that the nitrate concentration of groundwater in the Udunuwara area, vary between 1 to $62 \mathrm{mg} / \mathrm{l}$ (Figure 4). Relatively high nitrate levels were shown at several locations. The background nitrate level of the area was considered as approximately $6 \mathrm{mg} / \mathrm{l}$ according to the previous researchers (Dissanayake and Weerasooriya,1987; Padmasiri and Pitakumbura, 1995). Accordingly, 64\% of the sampled wells showed elevated nitrate levels. The periodical sampling of the groundwater from these dug wells revealed that the concentration of nitrates in groundwater varies considerably with time lapsed after the application of fertilizers to the adjacent paddy fields. Certain locations indicate the gradual reduction of nitrate levels in groundwater, with the laps of few weeks after the application of fertilizers. Location 2, (Figure 4) showed the maximum nitrate concentration of $62 \mathrm{mg} / \mathrm{l}$ as nitrate-N that already exceed the WHO (World Health Organization) recommended limits. Periodical sampling of this well commenced only a few days after the application of nitrogen fertilizer. This well is located close to the paddy field where the soil was very sandy in texture. Therefore, the gradual reduction of nitrate concentration at this location was considered to be as a result of dilution with nitrate free groundwater from upper reaches.

It was noted in some cases that the increased nitrate levels gradually decreased with time (Figure 5) with groundwater flow and mixing with nitrate 
free groundwater. It is important to note that certain dug wells and almost all the tube wells yield water with very low nitrate levels ranging from 1-5 $\mathrm{mg} / \mathrm{l}$ (Figure 6). However the nitrate values of deep tube wells remained constant throughout sampling whereas a few dug wells showed a remarkable increase of the nitrate levels upon adding fertilizer to the adjacent paddy fields (Gunatilake, 1998).

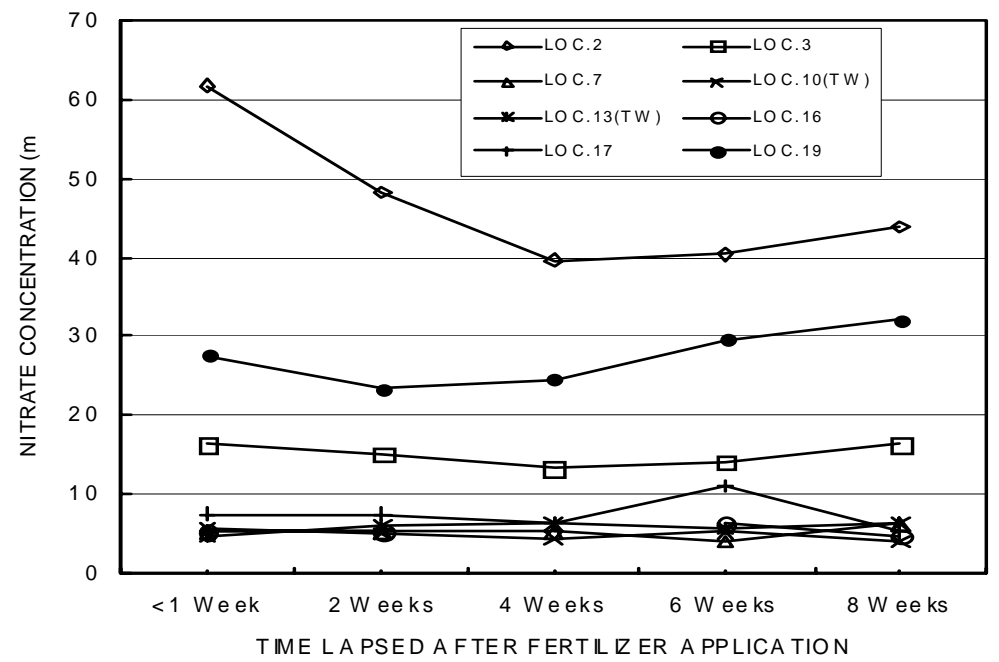

Figure 4: Variation of nitrate in groundwater with time after application of fertilizer(Udunuwara area, Kandy)

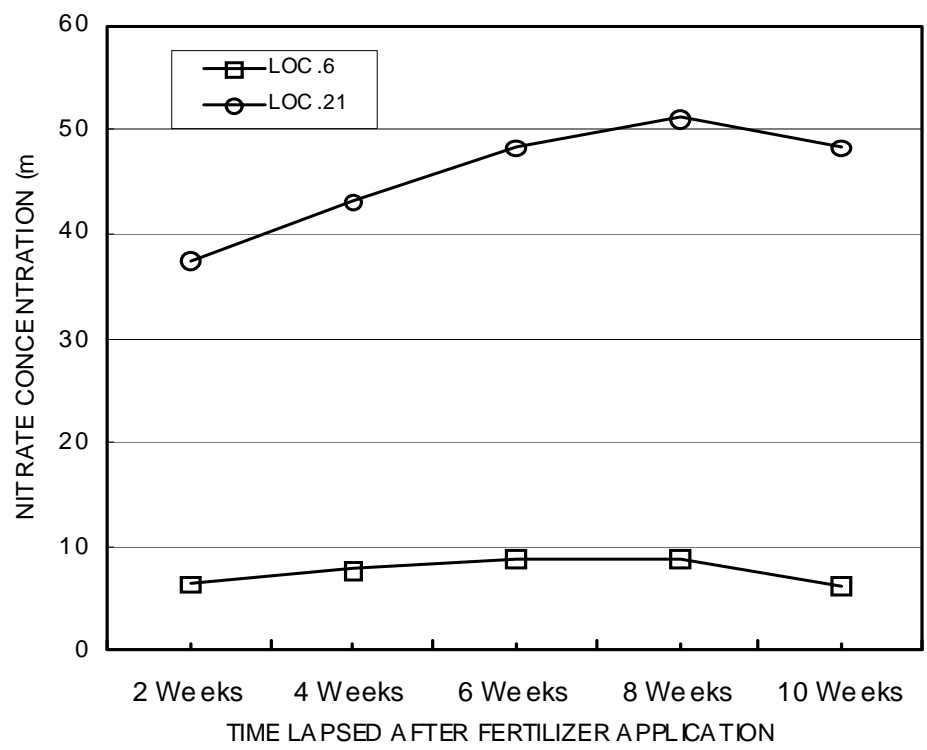

Figure 5: Tendency of decreasing nitrate levels after few weeks, as a result of groundwater flow (Udunuwara area, Sri Lanka) 


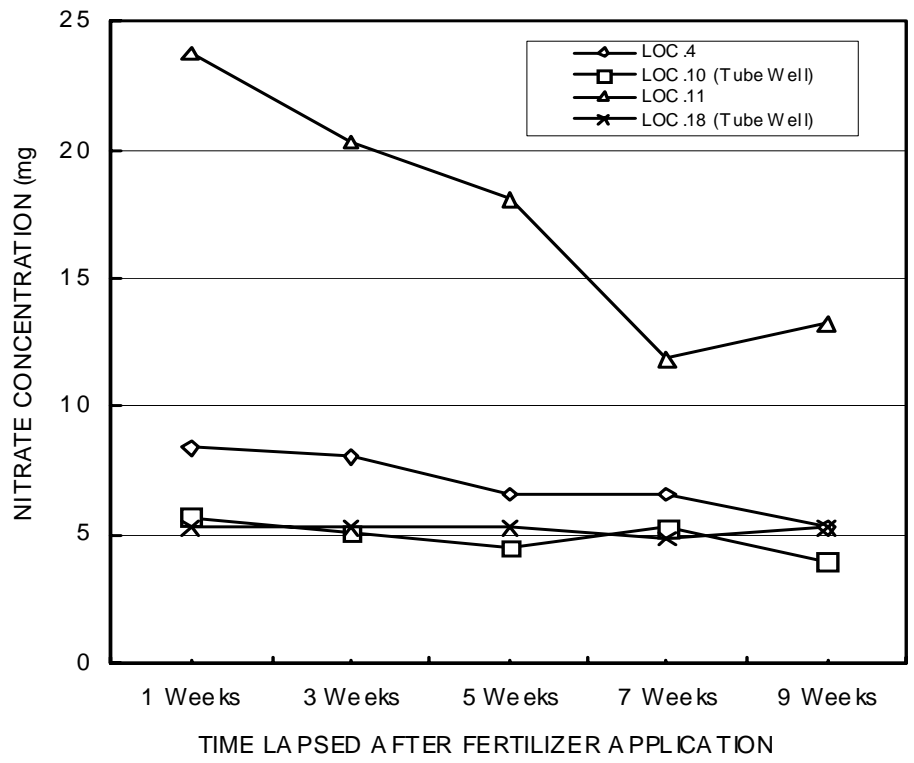

Figure 6: Difference between the variation of Nitrate in tube wells and dug wells (Udunuwara area, Sri Lanka)

Well no. 15 located right in the middle of a paddy field, could be regarded as a typical site for studying the effect of application of fertilizers to nitrate levels of groundwater. The groundwater table there was relatively deeper (at about 2-3 m depth and the soil was sandy in texture) and water was being pumped by an electric motor. Because of the relatively faster withdrawal of water by a pump, the well is continuously recharged by the groundwater below the paddy field. Therefore, a quick response of nitrate levels (Figure 7) could be observed against the adding of fertilizers to the adjacent paddy fields.

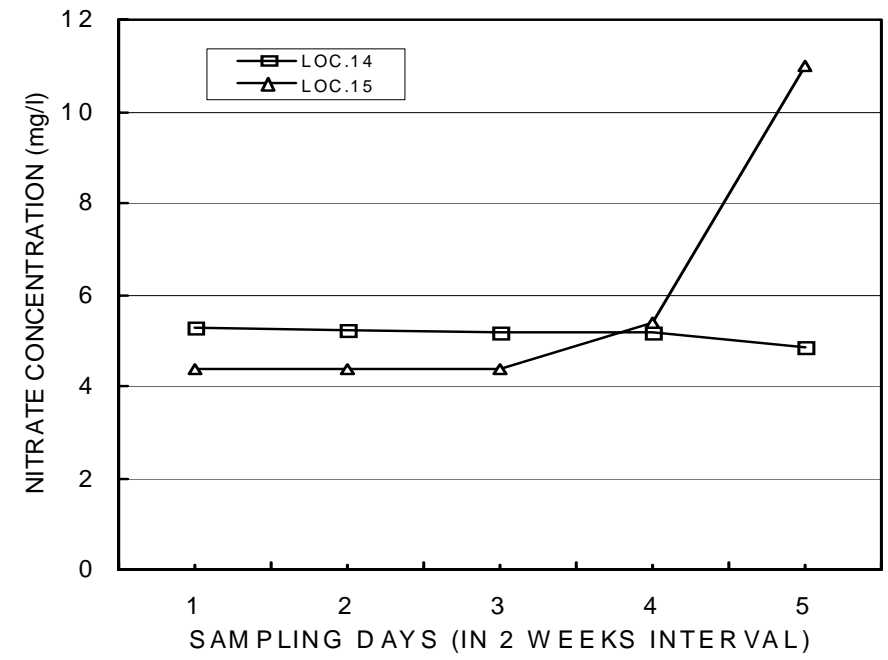

Figure 7: Behavior of Nitrate concentration Vs. time (Udunuwara area, Sri Lanka) 
The near constant nitrate levels of very low concentrations in samples from locations 8, 14 and 15 confirmed that the groundwater of that area is not being contaminated by nitrates as no fertilizer had been applied to the nearby paddy fields. There was no other possible nitrate contamination from any other source in the close proximity.

All the above observations were made assuming the natural sources of nitrate pollution to be negligible compared to the contribution from the nitrogenous fertilizers. But in certain cases, the natural contribution through the process of microbial degradation of organic nitrogenous material also could be significant. Further, farm animal wastes from cattle sheds, poultry farms and certain human excreta disposal practices (unprotected pit latrines etc.) would largely contribute to the nitrate concentration in groundwater. However during the selection of sampling sites, such possibilities have been avoided to the maximum extent.

(b) Case Study : Shiroishi Plain in Saga Prefecture in Japan

The chemical analysis results of the Shiroishi Plain were statistically analyzed and studied with respect to seasonal changes, various crop types cultivated, and the type of samples obtained (whether from the shallow tube well, deep tube well, sub-surface drainage pipes, interceptor drains, streams etc). Chemical analysis of the samples collected from the study area indicates that the nitrate concentration in groundwater varies between $0.1-60 \mathrm{mg} / \mathrm{l}$ as $\mathrm{NO}_{3}-\mathrm{N}$. The average nitrate level of the groundwater in Shiroishi plain was calculated to be $1.4 \mathrm{mg} / \mathrm{l}$ and considered as the background nitrate concentration of the area. The $\mathrm{pH}$ values of the all samples were ranged between 4 - 4.5. As pointed out by many researchers (Angle et.al., 1993, Hubbard et.al., 1987, Kanwar, et.al., 1995 and 1996, Spalding and Exner, 1993) the nitrate-N level above $1 \mathrm{mg} / \mathrm{l}$ of WHO levels indicates contamination. Accordingly, shallow groundwater in the large part of the study area is considered vulnerable for nitrate pollution after fertilization. Sixty four percent of samples analyzed did not show contamination as they had $\mathrm{NO}_{3}-\mathrm{N}$ levels less than $1 \mathrm{mg} / \mathrm{l}$. Twenty six percent of wells showed elevated nitrate concentrations of 1 to $3 \mathrm{mg} / \mathrm{l}$ as $\mathrm{NO}_{3}-\mathrm{N}$. Around $10 \%$ of the sampled wells showed nitrate contamination more than $3 \mathrm{mg} / \mathrm{l}$.

At a $\mathrm{pH}$ less than 6.0 the rate of the nitrification process in agricultural soils decreases and become negligible when $\mathrm{pH}$ is below 4.5 (Hart et.al., 1994). The $\mathrm{pH}$ of the study area ranged between 4-5 at the time of sampling. Although fertilization causes $\mathrm{pH}$ changes, the high cation exchange capacity of Ariake clay does not allow much change in $\mathrm{pH}$ in soil and that may be the reason for low nitrate concentrations in shallow groundwater in most areas. The ammonium concentration also was very low values. It can be believed 
that ammonium ions readily enter the interlayer portions of clays releasing $\mathrm{K}^{+}$ions into solution rapidly (Paul and Clark, 1989) due to main constituents of Ariake clay rather than the nitrification process. El-Shafei (2000) has carried out soil testing for Ariake clay for the same period and showed that the nitrate interaction with Ariake clay lattice, releases $\mathrm{Al}^{3+}$ and $\mathrm{OH}^{-}$ions into solution without representing the real nitrate level in shallow water. This special ability of the Ariake clay to absorb more nutrients within the lattice results in the accumulation of nitrate and ammonia ions in the upper soil layer without leaching.

Variation of $\mathrm{NO}_{3}-\mathrm{N}$ concentration in subsurface water in paddy and onion cultivated fields is shown in Figure 8 . The relatively low concentrations $(<1 \mathrm{mg} /$ 1) increased gradually from December to March, as onion is cultivated in the fields. Highest values were recorded in January-February samples after the application of fertilizers to the fields. The rapid decrease could be observed in May samples after harvesting onion. However most of this onion cultivated fields were later changed into paddy fields and the decreasing trend disappeared. The nitrate levels increased from the May sampling onwards due to fertilizer application for paddy cultivation. A somewhat similar variation pattern is observed in samples from corn and asparagus cultivated land. Even though the concentrations in December did not exceed $0.5 \mathrm{mg} / \mathrm{N} \mathrm{NO}_{3}$ $\mathrm{N}$, the levels were increased to $12 \mathrm{mg} / \mathrm{l}$ in March samples in asparagus cultivation land. Cabbage and barley cultivation showed a remarkable increase of $\mathrm{NO}_{3}-\mathrm{N}$ content in groundwater after fertilization and subsequent decrease with time. This difference of nitrate levels may be attributed to the different types and compositions of fertilizers applied to various crops and the different up taking capacity and the difference of drainage facilities.

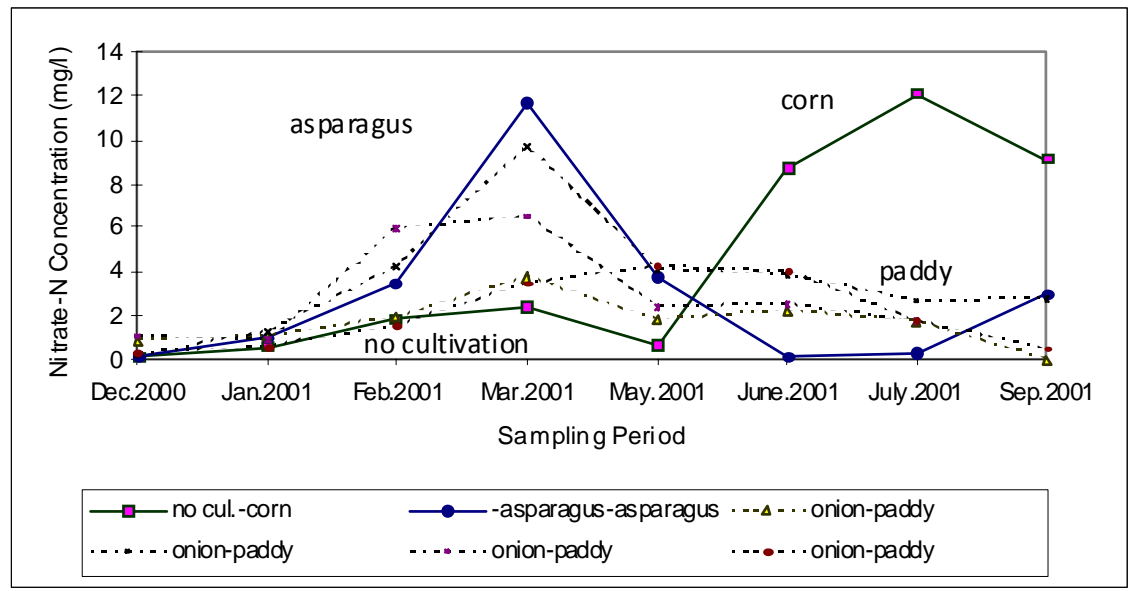

Figure 8: Variation of nitrate concentration in shallow well samples with crop type (Shiroishi Plain, Japan) 
Even though densely populated agricultural areas generally cause environmental problems, the influence of fertilization in the Shiroishi plain is a temporary process yielding much productivity to farmers in the area. In the first part of this study it was shown that research carried out in the lowland area in the Central Province of Sri Lanka (Dissanayake et.al., 1984) clearly showed that cultivated and irrigated soils contaminate the shallow aquifer by nitrates derived from fertilizers. In the Udunuwara area there was sandy soil and the shallow groundwater level was deeper than that of the Shiroishi plain. Apart from the groundwater depth difference, the special ability of Ariake clay to absorb nutrients has protected from contaminating the shallow water in the Shiroishi Plain.

Figure 9 shows a comparison of the variation of the $\mathrm{NO}_{3}-\mathrm{N}$ within the well, drainpipes and nearby interceptor drain/creeks. It clearly indicates the low nitrate levels in wells and relatively high levels in drainpipes and elevated Nitrate-N concentrations in surface water of drains. Different nitrate levels in different locations may be due to different fertilizer application rate and crop type. The average $\mathrm{NO}_{3}-\mathrm{N}$ value observed in sampled subsurface drainage pipes was $8 \mathrm{mg} / \mathrm{l}$, which could be considered a significantly elevated figure. It also showed that the average nitrate levels in the subsurface drainage pipes are different from those in the sample wells and interceptor drains. This difference may be due to climatic changes, irrigation practices as well as fertilization. However, the high nitrate level in subsurface drainage means that there is significant leaching of the nutrients from the Ariake clay. The subsurface drainage system therefore reduces the nutrients in soil that had accumulated from fertilization from affecting the surface water. As the water with excess nutrients is added to interceptor drains through drainpipes, the water from interceptor drains become dark green and emanates a bad odour.

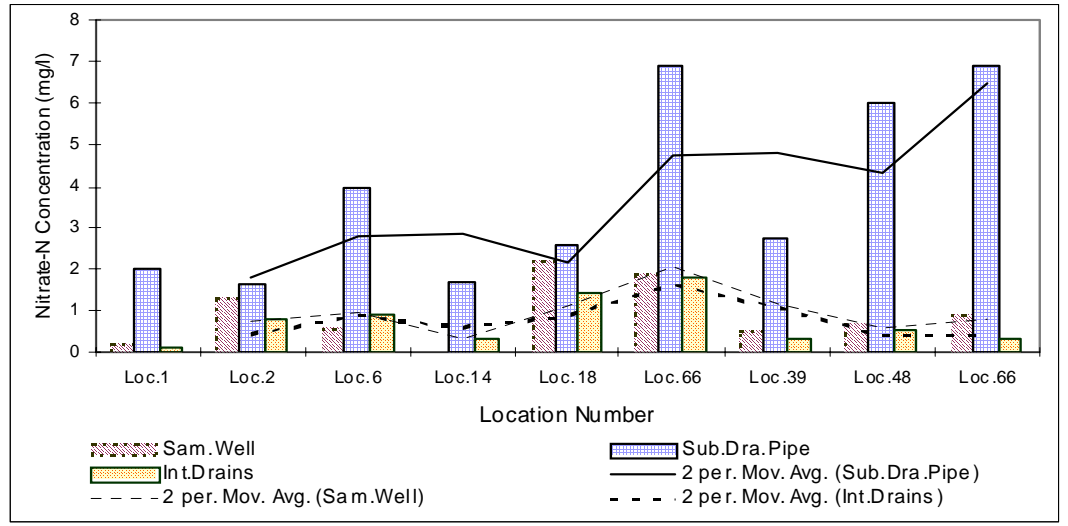

Figure 9: Comparison of the Variation of the $\mathrm{NO}_{3}-\mathrm{N}$ within the Wells, Drain pipes and Nearby Interceptor Drain/Creeks (Shiroishi Plain, Japan) 
As the main shallow groundwater flow in the Shiroishi Plain is horizontal (Miura et al., 1988 and Onitsuka, 1988) the following one-dimensional analytical model is used to predict how the deep groundwater table is affected by these agricultural activities. The land reclaimed 50 years before, (very close to the shore) showed a high solute velocity compared to the other areas in Saga Prefecture. The low velocity variation patterns are probably due to consolidation of soil over a period of many years. The upper soil layer of the study area from the surface was assumed as a homogeneous layer and the initial concentration was constant. According to this boundary condition at time " $\mathrm{t}$ ", the concentration of the solute in distance " $\mathrm{z}$ " is given by the following equation 1(a) (Ogata, 1970). Analytical solutions of this equation have been expressed in graphical form suitable for hand computation (Ogata, 1970; Booker and Rowe, 1987).

$$
\begin{aligned}
& \begin{array}{llll}
\mathrm{C}(\mathrm{z}, 0) & = & 0 & \mathrm{z}>0 \\
\mathrm{C}(0, \mathrm{t}) & = & \mathrm{C}_{0} & \mathrm{t} \geq 0 \\
\mathrm{C}(\infty, \mathrm{t}) \quad= & 0 & \mathrm{t} \geq 0
\end{array} \\
& \frac{C}{C_{0}}=\frac{1}{2}\left\{\operatorname{erfc}\left(\frac{(z-v t)}{2(D t)^{\frac{1}{2}}}\right)+\exp \left(\frac{v z}{D}\right) \operatorname{erfc}\left(\frac{z+v t}{2(D T)^{\frac{1}{2}}}\right)\right\}
\end{aligned}
$$

Where

$$
\operatorname{erfc}(x)=1-\operatorname{erf}(x)=1-\frac{2}{\sqrt{\pi}} \int_{0}^{x} e^{-u^{2}} d u
$$

$\mathrm{D}=$ Diffusion coefficient in unsaturated soil

$\mathrm{v}=$ ground water flow velocity

$\mathrm{t}=$ time of interest

$\mathrm{z}=$ depth of interest

The $\mathrm{z}$ values calculated from solute conservation equation as follows. Negatively charged and highly soluble ions do not react chemically (except for anion exclusion) and they are not attracted to clay or organic matter surfaces. Therefore $\mathrm{C}_{\mathrm{a}}, \mathrm{C}_{\mathrm{g}}$ and $\mathrm{r}_{\mathrm{s}}$ values can be negligible.

$$
\frac{\partial C_{T}}{\partial t}+\frac{\partial J_{s}}{\partial z}+r_{s}=0
$$

(solute conservation equation) 
$C_{T}=\rho C_{a}+\theta C_{l}+a C_{g}$ $1(\mathrm{c})$

where

$\mathrm{C}_{\mathrm{T}}$ - total solute concentration

$\mathrm{C}_{\mathrm{a}}-$ adsorbed solute concentration

$\mathrm{C}_{\mathrm{g}}$ - gaseous solute concentration

$\mathrm{C}_{1}^{\mathrm{g}}$ - dissolved solute concentration

$\rho$ - bulk density

$\theta$ - volumetric water content

$\mathrm{J}_{\mathrm{s}}-$ total solute flux

$\mathrm{t}$ - time of interest

Figure 10 indicates the variation of nitrate leaching only by pure diffusion process. This figure shows that solute (nitrate) concentrations ratios in a large part of the area are completely become zero around $0.7 \mathrm{~m}$ depth from the surface. The results show in figure 10, fits well with one of the most important observations made during the analysis of data collected from this study area. It is observed that the nitrate leaching takes place mainly within the upper most layers $(0-0.6 \mathrm{~m})$ and is not likely to extend to the low permeable Ariake clay. Accordingly there is no possibility of polluting deep water due to the application of fertilizers.

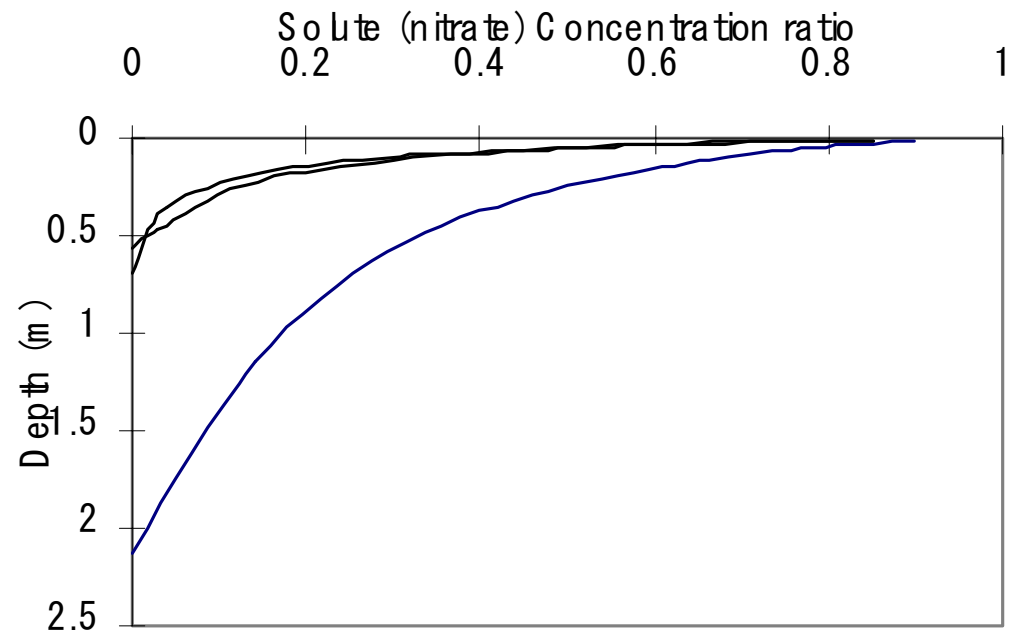

Figure 10: Variation of Nitrate leaching through soil by diffusion (Shiroishi Plain, Japan) 


\section{Conclusions}

According to the results obtained, it could be concluded that the application of nitrogenous fertilizer in Sri Lanka has a direct impact on the concentration of nitrates in groundwater in the vicinity. The time taken for nitrates to reach the groundwater table varies due to factors such as groundwater flow and direction, depth to groundwater table, nature of subsurface material (whether sandy or clayey), and the rate of withdrawal of water. The high nitrate input by the application of fertilizers into groundwater can be considered as a temporary process and nature itself gradually acts to remove the excess nitrates by continuous flow of groundwater. Low Nitrate levels in deep tube wells indicate that deep groundwater is not mixed with the shallow groundwater, which is usually contaminated with nitrates from paddy fields or other sources. The effect of the application of nitrogenous fertilizers is very little or negligible in the case of deep tube wells. Hence, in areas where the agricultural practices are intensive, water from tube wells can be considered safer for human use. Groundwater contamination in unfertilised land is substantially low, whereas in areas where groundwater nitrate concentration is high, there might be a substantial risk that pesticides may also be leached below the soil zone contaminating the potable groundwater supplies. Careful attention must be paid when water is withdrawn for drinking purpose, from wells near paddy fields and also during periods of fertilizer application to paddy fields if drinking water wells are located nearby.

According to the results of the study carried out in Japan, it can be concluded that the, many current intensive systems of vegetable production are not sustainable in this way, because they cause significant ecological damage. Growers usually apply large amounts of nitrogen fertilizer to obtain high yields of good quality. This may be sound from an economic perspective, but not from an environmental perspective. Often, large amounts of nitrogen remain in the soil after a vegetable crop is harvested. The rate of leaching depends on the crop rotation, fertilizer type and amounts used, crop type, climatic condition and cation exchange capacity of the soil. Removal of nitrate through the subsurface drainage system prevents the leaching of much nitrate into groundwater. It is also noticed that high cation exchange capacity of Ariake clay is beneficial to farmers without affecting the environment. However the Ariake clay is a very good soil for agricultural practices if the application of fertilizer is controlled properly. Because of its low permeability, Ariake clay can be used as a protecting layer for any contaminant management practices. The shallow groundwater table is highly vulnerable for non-point source pollution in agricultural beds whereas the deep groundwater shows less nitrate contamination. 


\section{References}

Angle J.S., Gross C.M., Hill R.L. and McIntosh, M.S. (1993) Soil nitrate concentrations under corn as affected by tillage, manure, and fertilizer applications. Journal of Environmental Quality. v. 22(1), pp. 141-147.

Booker, J.R. and Rowe, R.K. (1987) One dimensional advective-dispersive transport into a deep layer having a variable surface concentration. International Journal for Numerical and Analytical Methods in Geomechanics, v. 11(2), pp.131-142.

Dissanayake, C.B., Weerasooriya, S.V.R. and Senaratne, A. (1984) The distribution of nitrates in the potable waters of Sri Lanka, Aqua No.1, pp. 43-50.

Dissanayake, C.B. and Weerasooriya, S.V.R. (1987) Medical Geochemistry of Nitrates and Human Cancer in Sri Lanka. International Journal of Environmental Studies, v. 30, pp. 145-156.

El-Shafei, A.A. (2000) Geo-environmental and geotechical assessments of nitrate polluted soil. Ph.D. thesis, Saga University, Japan.

Gunatilake, S.K. (1998) Appraisal of nitrate contamination of groundwater by intensive use of fertilizer around Kandy area in Maha Season, MSc Thesis, Postgraduate Institute of Science, University of Peradeniya, Sri Lanka

Hart, S.C., Stark, J.M., Davidson, E.A. and Firestone, M.K. (1994) Nitrogen mineralization, immobilization and nitrification. In "Methods of soil analyses", Part 2, "Microbiological and biochemical properties", Soil Science Socity. Am., Madison, Wisconsin:, pp. 985-1018.

Hubbard, R.K., Thomas, D.L., Leonard, R.A. and Bulter, J.L. (1987) Surface runoff and shallow groundwater quality as affected by center pivot applied dairy cattle wastes. Transactions of the ASAE., v.30(2), pp. 430-437.

Kanwar, R.S., Karlen, D., Cambardella, C. and Cruse, R.M. (1995) Swine manure and $\mathrm{N}$-management systems, Impacts on groundwater. In Proc. Natural Conference of Water Quality: Clean Water Clean Environment$21^{\text {st }}$ Century, St. Joseph, Mich.: ASAE. pp. 91-94.

Kanwar, R.S., Colvin, T.S., Karlen, D., Cambardella, C., Cruse, R.M. and Pederson, C. (1996) Impact of manure and N-management systems on water quality. International Proceeding of Integrated Crop Mgt. Conf., Iowa State University, Extension, Ames, Iowa. 
Miura, N., Taesiri, Y., Sakai, A. and Tanaka, M. (1988) Land subsidence and its influences to geotechnical aspects in Saga plain, , International Symposium of Saga Lowland, Saga, Japan, pp.151-159.

Nakamura, R., Onitsuka, K., Aramaki, G. and Miura, N. (1985) Geotechnical properties of the very sensitive Ariake clay in Saga Plain. Symposium on Environmental Geotechnics and problematic soils and rocks, Asian Institute of Technology, Bangkok, Thailand, pp. 888-910.

Ogata, A. (1970) Theory of dispersivity in a granular medium. US Geological Survey, Professions Paper 411-A.

Onitsuka, K. (1988) Mechanical properties of very sensitive Ariake clay, International Symposium of Saga Lowland, Saga, Japan, pp.159-169.

Padmasiri, J.P. and Pitakumbura, D.G.S.W. (1995) Bacteriological, chemical and geological characteristics of hand-pump wells in Udunuwara area, Kandy District, Journal of Geological Society of Sri Lanka, v.3, pp. 33-40.

Paul, E.A. and Clark, F.E. (1989) Soil microbiology and biochemistry. In: Amonification and nitrification, United State, America, pp. 181-245.

Spalding, R.F.and Exner, M.E. (1993) Occurrence of nitrate groundwaterA review. Journal of Environmental Quality, v. 22(3), pp. 392-402. 